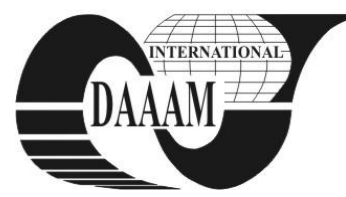

Annals of DAAAM for 2011 \& Proceedings of the 22nd International DAAAM Symposium, Volume 22, No. 1, ISSN 1726-9679 ISBN 978-3-901509-83-4, Editor B. Katalinic, Published by DAAAM International, Vienna, Austria, EU, 2011 Make Harmony between Technology and Nature, and Your Mind will Fly Free as a Bird

\title{
USAGE OF ASSEMBLY AND INTELLIGENCE IN FLEXIBLE ASSEMBLY CELL
}

\author{
MATUSOVA, M[iriam]; HRUSKOVA, E[rika] \& JAVOROVA, A[ngela]
}

\begin{abstract}
Continuous development in production engineering and the increasing of production automation affects to the modifications of the technical parameters of production machinery and tools. There has been a steady increase in production flexibility, which ensures the possibility of an effective piece and small batch production. This fact is closely linked to the need to shift production to machines with high flexibility by shortening time and logistics flexibility. One way of the above requirements improving is the use of elements of intelligence and aspects or the basic principles of assembly.
\end{abstract}

Key words: cell, assembly, intelligence, manufacturing, process

\section{INTRODUCTION}

Cellular structures achieve consistency between machines, saving time and space. Machine process is synchronized, material flow is fast (move parts from machine to machine is in a short distance). Manufacturing cells make together and take advantages of many other types of production (eg. from mass production of dedicated machines to particular production rate of one-off and from small batch production on $\mathrm{CNC}$ machines, especially the flexibility of production.)

Introducing technology to block production in flexible manufacturing cells to give high production flexibility and to the small number of parts in batches applies in particular to achieve a fluidity of movement of material, quality assurance and the slenderness of the production process and the economic effects reporting of mass production.

\section{ASSEMBLY PROCESS IN CELL}

Modern manufacturing is currently located in production areas and production areas require the integration of different types of engineering and manufacturing operations. Therefore production philosophy allowing the integration of control, organizational, monitoring and other innovative type of activities into one unit is needed. Due to the relatively high variability of real production technologies, dominant technologies, production volumes, production flows, production use funds and many others, further consideration and analysis of the problem are focused on area of modern automated, especially robotized production. Creation and design of automated assembly system is a complex problem, which includes design problematic of automated device. (Javorova et al., 2009).

Assembly is a set of different activities, through which the individual components of creating a functional unit (machine, equipment, etc.). Decisive influence not only the quality and reliability of products, but also for continuous production, productivity and efficiency throughout the production system. Assembly is a very laborious and costly operation. The cost of fitting it possible to reduce the principles of technology structures, particularly the use of standardized, respectively unified components, the simplest ways of joining parts. Assembly procedure is the rule being followed in bringing together the components into higher units. In general, the production assembly procedures are based on:

- Product design documentation - drawings of components, assemblies, and technical reports identifying the size of moments screws and so on;

- The existing machinery and tooling;

- Normative standards for determining time for each assembly operations.

Prototype of assembly cell in our institute is designed for small batch production. According to this, the assembly process is characterized by stationary assembly described by:

- Assembly is realised in a place;

- Is realised by standard assembly methods without detailed limited time (time standards), and progress determinates only sequence of assembly operations and for each operation defines devices, tools etc.

The advantage of the stationary assembly is a big change in the manufacturing workplace flexibility program, disadvantages lie in the long interim period of assembly of large claims on qualifications and work areas. It is used in the piece and small batch production. Model of assembly cell used the principles of flexible assembly automation where the process is realised by automation equipments with defined position of assembled components, with programming assembly and manipulating equipments, and with technological equipments for realisation of assembly processes. Generally, the successful implementation of the automatic assembly of any product must meet the conditions arising from:

- Sufficient workpiece serial production;

- Technology construction;

- Workpiece parts of component;

- Suitable assembly technologies;

- Generally the main aim of production and manufacturing process is to reduce the costs of assembly;

- Integrated parts (Advantages and Disadvantages);

- Maximize ease of assembly;

- Consider customer assembly.(Horvath et al., 2009)

One of the steps how to make effective assembly is to minimize ease of assembly. It means for example:

- Part is inserted from the top of the assembly;

- Part is self-aligning;

- Part does not need to be oriented;

- Part requires only one hand for assembly;

- Part requires no tools;

- Part is assembled in a single, linear motion;

- Part is secured immediately upon insertion;

- Consider customer assembly;

- Customers will tolerate some assembly;

- Design product so that customers can easily and assemble correctly;

- Customers will likely ignore directions.

The success of the assembly automation largely decided and it is also important in addition to hardware quality 
assurance and technical preparation of production assembly. (Ruzarovsky et al., 2010). One of the prerequisites for the automation of the assembly is mounted to ensure the availability of parts. This requires introducing a strict application of certain design interventions that take into account the mounting requirements. This is an application of technology assembly. In automated assembly, it is necessary the components constructed to be as simple positioned and assembly as far as possible takes place in one direction.

\section{CELL MODEL IN INSTITUTE OF MANUFACTURING SYSTEMS AND APPLIED MECHANICS}

Model of flexible manufacturing cell at the Institute of Technological Systems and Applied Mechanics in Faculty of Material Science and Technology of Slovak University of Technology in Trnava (Fig.1) is a multi-handling production assembly equipment to integrate the five stages of production, has to pass through each product during its production, namely:

- Intermediate storage and transportation of production equipment by angular robot;

- Machining of semi-finished component;

- Handling the various components;

- Assembly of individual components into a finished product;

- Final product handling and storage prior to dispatch.

The main problem for projecting and design of this assembly cell is solving of material movement. (Zvolensky et al., 2009) It is necessary to define particular groups of components named "group technology".

Basic principles for the design of transport and handling were determined using the necessary input data and set the desired outcomes which then can be applied to the model of organization and management process. In increased level of mechanization and automation of the manufacturing process increases the importance of design choice and design of handling facilities. The importance of handling equipment highlights the fact that in manufacturing processes and handling operations is needed more than half of the total time so far, and that their level of automation is much lower than that of technological operations.

Devices for manipulation (Fig.2) in addition to the storage are allocated to:

- The manufacturing process of each component,

- Assembly or finished product usually does not take a single workplace, but material must be moved. (Holubek et al., 2010)

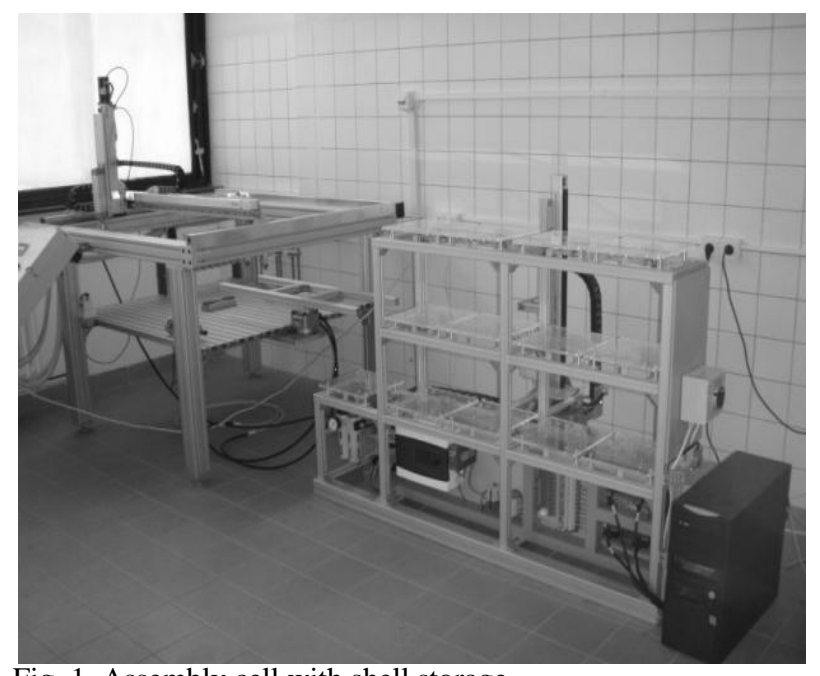

Fig. 1. Assembly cell with shell storage

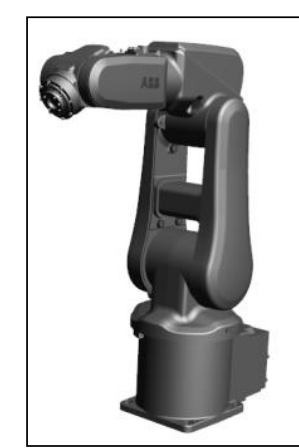

Fig. 2. Angular robot IRB 120 used to paletization of assembly semiproducts

\section{CONCLUSION}

With this phenomenon relates many problems especially with inventory planning, organization of production, rationalization of work. In particular, large enterprises have adapted to the nature of their production to mass production, creates a huge problem with optimization of inventory both in storage and manufacturing, production optimization problems, with frequent alterations of machinery and related timing, capacity and economic losses. The Institute of Production Systems and Applied Mechanics is dedicated to design of intelligent assembly cell interconnected, principles of rational and efficient assembly and of the intelligence basic principles. So far, however, is not resolved the directing and controlling of cell (automated exchange of grips, the handling of individual components assembled parts, etc.), in which the cell processes. Through the resolutioning problems withplanning, designing and simulation, the researchers in our institute tra to minimize downtime, scraps and take away critical places with manipulation and all material flow.

\section{ACKNOWLEDGEMENTS}

This paper was created thanks to national project VEGA $\mathbf{1 / 0 2 0 6 / 0 9}$ Intelligent assembly cell.

\section{REFERENCES}

Horvath, S.; Ružarovsky, R.; Velisek, K. (2009) Structures of flexible assembly cells. In: Scientific Bulletin, ISSN 12243264, Vol. XXIII, pp. 53-58

Javorova, A.; Zvolensky, R.; Pechacek, F. (2009) Methodology and design of automated disassembly device. In: MMA 2009. Flexible Technologies: Proceedings. 10th international scientific conference. - Novi Sad, 9.-10.10. 2009, ISBN 978-86-7892-223-7

Holubek, R.; Velisek, K.; Kostál, P. (2010). Automatization manipulation of workpieces by "Pick and Place" manipulator. In: ROBTEP 2010: $10^{\text {th }}$ conference of Automation/ Robotics in theory and praxis: Bardejov, Slovakia, 7-9 June 2010. Bardejov: ISBN 978-80-5530427-4, pp.135-144

Ruzarovsky, R.; Zvolensky, R.; Velisek, K. (2010). Proposition of design methodology for generation of automated assembly devices. In: Proceedings of the 7th International Conference of DAAAM Baltic Industrial Engineering: Tallinn, Estonia 22-24 April 2010, Tallinn: ISBN 978-9985-59-982-2, pp. 90 - 95

Zvolensky, R.; Velisek, K.; Kostal, P. (2009). Flexible disassembly robot with cartesian structure. In: RAAD 2009: 18th International Workshop on Robotics in AlpeAdria-Danuve Region. Romania, Brasov, May 25-27, 2009, ISBN 978-606-521-315-9 